\title{
PENGARUH ORIENTASI PASAR DAN KREATIFITAS TERHADAP KINERJA PEMASARAN AIR MINUM DALAM KEMASAN (AMDK) PADA PT. UMEGA SEMBILAN BERLIAN GUNUNG MEDAN DHARMASARAYA
}

\author{
Muhammad Aldo, Riri Mayliza \\ Sekolah Tinggi Ilmu Ekonomi KBP \\ muhammad.aldo77@gmail.com \\ ririmayliza@akbpstie.ac.id
}

\begin{abstract}
ABSTRAK
This study aims to determine the effect of market orientation and creativity on the marketing performance of bottled drinking water (AMDK) in PT gunung medan Dharmasraya. The variables in this study are Market Orientation (X1), Creativity (X2) and Marketing Performance (Y). 67 stores were used, the sampling technique used was saturated sampling method. Data collection used questionnaires, while data analysis techniques were carried out using multiple linear regression analysis. The results showed that market orientation variables had a positive and significant effect $(0,000<0,005)$ and creativity had a positive and significant effect $(0,000<0,005)$ on marketing performance. It is expected that the next researcher can use the research as a reference which will later provide a comparison in conducting further research and beneficial for the company.
\end{abstract}

Keyword: Market orientation, creativity, marketing performance.

\section{PENDAHULUAN}

Setiap perusahaan mempunyai tujuan yang sama untuk mewujudkan pertumbuhan dan kelangsungan hidupnya untuk jangka panjang. Dalam perekonomian modern yang ditandai dengan persaingan yang sama karena tujuan dan kompleks serta tingkat akselerasi yang tinggi, oleh karena itu perusahaan dituntut guna mendapatkan keahlian pengembangan pilihan strategi di aspek manajemen pemasaran maka sanggup menyesuaikan dengan wilayah sekitar.

Dalam situasi seperti ini, pelanggan harus menuntut (demanding) untuk dapat memperoleh tingkat kualitas produk atau jasa yang tinggi dengan harga murah, sehingga penting bagi perusahaan untuk mengembangkan orientasi pasar agar dapat bertahan di lingkungan yang dinamis. Air minum dalam kemasan (AMDK) merupakan larutan utama yang sudah menjalani sebentuk sistem pengibiran, disimpan, dan terlindung buat diminum meliputi air mineral serta air demiineral. Jumlah tahun belakang ini pemasaran air minum dalam kemasan (AMDK) di Indonesia meningkat amat cepat, makasampai-sampai timbul rivalitas bagaimana menghasilkan air minum yang patut diminum oleh masyarakat. Ada yang mengatakan air minum mineral, ada juga air minum murni, karena keunikan yang bermacam-macam juga. Keadaan tertulis ternyata melahirkan pertentangan 
prinsip air mineral dan air murni disekelompok para ahli dan penghasil air minum.Permasalahan yang sering muncul dalam pemasaran Air Minum Dalam Kemasan (AMDK) PT. Umega Sembilan Berlian yaitu masuknya para pesaing produk air minum dalam kemasan lain di Daerah pemasaran yang dilakukan oleh PT. Umega Sembilan Berlian selama ini, kurangnya kreatifitas dari segi pembaruan kemasan dari Perusahaan, Dan PT. Umega Sembilan Berlian belum berani untuk mencoba memasarkan produknya ke Daerah yang belum dipasarkan sebelumnya.Hal ini mengakibatkan menurunnya tingkat penjualan PT. Umega Sembilan Berlian, oleh sebab itu dalam strategi penguatan daya saing dari segi mutu dan kemasan yang harus dilakukan PT. Umega Sembilan Berlian adalah harus selalu diperbarui dalam mengahadapi competitor yang semakin mengeluarkan produk-produk terbaru seperti model kemasan yang baru dan mutu air yang selalu terjamin mulai dari pengem/asan sampai ke tangan konsumen dan mencoba mengembangkan pemasaran ke Daerah yang belum terjamah sebelumnya.

\section{METODE PENELITIAN}

\section{Populasi dan Sampel}

Populasi yaitu wilayah generalisasi yang terdiri atas subjek atau objek yang memiliki kuantitas dan karakteristik tertentu yang ditetapkan

mewakili (Sugiyono 2015).Keseluruhan populasi tidak mungkin dapat diteliti karena keterbatasan biaya, tenaga, dan waktu. Dapat disimpulkan bahwa sampel harus bisa mewakili keseluruhan subjek ataupun objek dalam penelitian. Dalam penelitian ini teknik pengambilan sampel yang digunakan adalah sampling jenuh dimana sampling jenuh merupakan teknik pengambilan sampel bila semua anggota populasi digunakan sebagai sampel (Sugiyono 2015). Sampel yang digunakan sebanyak 67 toko pada pedagang yang menjual produk air minum Airumeg PT.Umega Sembilan Berlian Gunung Medan, Dharmasraya Sumatera Barat.

\section{Defenisi dan Operasional Variabel}

Dalam penelitian ini terdapat dua jenis variabel yaitu variabel bebas dan terikat. Adapun yang berperan sebagai variabel bebas adalah orientasipasardankreatifitasdan kinerjapemasaran sebagai variabel terikat.

\section{Teknik Pengumpulan Data}

\section{Kuisioner}

Kuisioner yaitu teknik pengumpulan data yang dilakukan dengan cara memberi beberapa pertanyaan dan pernyataan tertulis kepada responden untuk dijawabnya (Sugiyono 2015). Oleh karena itu, pemberian beberapa pernyataan kepada para anggota sampel (responden) disebut juga kuisioner.

\section{Teknik Analisis Data}

Teknik analisis data yang digunakan adalah analisis deskriptif, uji validitas dan reabilitas, uji asumsi klasik dan analisis regresi linearberganda.

\section{Hasil dan Pembahasan}

Jumlah kuesioner yang diedarkan kepada responden sebanyak 67 eksamplar, seluruh kuesioner kembali seutuhnya karena penyebaran kuesioner dengan cara memberikan secara langsung dan ditunggu hingga selesai. 


\section{Uji Validitas dan Reabelitas}

Uji vadilitas merupakan suatu langkah pengujian yang dilakukan terhadap isi (konten) dari suatu instrumen yang digunakan dalam suatu penelitian (Sugiyono 2015). Dengan demikian uji vadilitas merupakan pengukuran ketepatan atau kevalidan dalam suatu instrumen yang diukur dan suatu alat ukur dapat dikatakan mempunyai validitas tinggi apabila dapat dijalankan peran ukurnya atau membagikan dampak ukur yang cocok dengan maksud dan tujuan dari diadakannya tes atau penilaian tersebut.

Validitas satu butir permasalahan bisa diketahui atas output Statistical Program For Social Science (SPSS) pada pada tabel melalui judul Item-Total Statistisc. Suatu butir masalah dikatakan valid bila nilai dari Corrected Item-Total Corrected $>0,30$. Uji validitas selayaknya dilakukan secara terbagi pada lembaran kerja yang berlainan antara satu konstruk variabel dengan konstruk variabel yang lain sehingga bias kedapatan butir-butir permasalahan variabel mana yang sangat banyak tidak valid dan variabel dikatakan handal (realiabel) Bila memiliki nilai cronbach's alpa minimal 0,70 (Sekaran,2006).

Tabel 1

Uji Validitas dan Reliabilitas

\begin{tabular}{|c|c|c|c|c|c|}
\hline Variabel & $\begin{array}{c}\text { Jumlah } \\
\text { Butir } \\
\text { Pernyataan }\end{array}$ & $\begin{array}{c}\text { Butir } \\
\text { Tidak } \\
\text { Valid }\end{array}$ & $\begin{array}{c}\text { Butir } \\
\text { Valid }\end{array}$ & $\begin{array}{c}\text { Cronbach's } \\
\text { Alpa }\end{array}$ & Keterangan \\
\hline $\begin{array}{c}\text { Kinerja } \\
\text { pemasaran }\end{array}$ & 5 & - & 5 & 0,884 & Reliable \\
\hline Orientasi pasar & 7 & - & 7 & 0.786 & Reliable \\
\hline Kreatifitas & 5 & - & 5 & 0.883 & Reliable \\
\hline
\end{tabular}

\section{UjiMultikolinearitas}

Uji multikolinearitas bertujuan untuk menguji apakah model regresi ditemukan adanya korelasi antar variabel bebas (independen), model regresi yang baik seharusnya tidak terjadi korelasi diantara variabel independen (Ghozali 2011)

\section{Uji Asumsi Klasik}

Uji asumsi klasik yang digunakan yang digunakan pada penelitian ini adalah, uji normalitas, heteroskedastisitas dan multikoleniaritas.

Uji normalitas adalah pengujian untuk mengkaji kenormalan variabel yang diteleti apakah data tersebut berdistribusi normal atau tidak (Sugiyono 2015). Bisa disimpulkan maka uji normalitas untuk melihat tingkat kenormalan variabel yang diteliti. Indikator yang digunakan Uji kolmogrov-smirnov dengan pedoman yaitu :

a. Jika nilai signifikansi $>0,05$, maka berdistribusi normal

b. Jika nilai signifikans $<0,05$, maka tidak berdistribusi normal.

Indikator uji multikonearitas yaitu apabila nilai tolerance $>0,1$, dan Variance Inflation Factor (VIF) $<10$ maka tidak terjadi gejala multikonearitas sehingga tidak adanya pengaruh antara variabel yang satu dengan variabel yang lainnya.

Uji heteroskedatisitas bertujuan menguji apakah dalam model regresi terjadi ketidaksamaan varians dari residual satu pengamatan kepengamatan yang lain. Apa bila varians pada residual satu pengamatan kepengamatan lain tetap, hingga disebut homoskedatisitas dan jika berbeda disebut heteroskedatisitas. Model regresi yang baik ialah yang homokedastisitas atau tidak terja diheteroskedatisitas 
(Ghozali 2011). Uji yang dipakai untuk mendeteksi ada atau tidak nya masalah heteroskedatisitas, yaitu :

\section{UjiGlejser}

Salah satu cara untuk melihat adanya problem heteroskedastisitas adalah dengan menggunakan uji glejser, dengan ketentuan jika nilai signifikasinya > 0,05 dapat disimpulkan jenis regresi tidak terjadi persoalan heteroskedastisitas.

\section{Analisis Regresi Linear Berganda}

Tujuan menggunakan analisis regresi linear berganda dalam penelitian ini adalah untuk mengetahui pengaruh Orientasipasar (X1), kreatifitas(X2)terhadap kinerjapemasaran (Y). Hasil dari analisis regresi linear berganda yang diolah dengan SPSS, dapat diringkas pada Tabel sebagai berikut:

\section{Tabel 2}

Hasil Uji Regresi Linear Berganda

\begin{tabular}{|l|l|l|l|l|}
\hline $\begin{array}{l}\text { Variabel } \\
\text { Terikat }\end{array}$ & $\begin{array}{c}\text { Konstanta dan } \\
\text { variabel Bebas }\end{array}$ & $\begin{array}{c}\text { Koefisien } \\
\text { Regresi }\end{array}$ & Signifikan & Keterangan \\
\hline $\begin{array}{c}\text { Kinerjapema } \\
\text { saran } \\
(Y)\end{array}$ & Konstanta (a) & 0,818 & 0,076 & \\
\cline { 2 - 5 } & Orientasipasar & 0,479 & 0,000 & H1 Diterima \\
\cline { 2 - 5 } & Kreatifitas & 0,309 & 0,000 & H2 Diterima \\
\hline
\end{tabular}

Iliki nilai signifikan lebih kecil dari $\alpha=0,05$.

Berdasarkan hasil analisis regresi linear berganda diatas, diperoleh persamaan regresi linear berganda:

$$
\mathrm{Y}=0,818+0,479(\mathrm{XI})+\mathbf{0 , 3 0 9}(\mathrm{X} 2)+\mathrm{e}
$$

Hasil analisis regresi lineaar berganda dapat diintrepretasikan bahwa variabel orientasi dan krearifitas berpengaruh positif dan signifikan terhadap kinerja pemasaran air minum dalam kemasan ( $a m d k)$.

\section{HASIL DAN PEMBAHASAN}

\section{Pengaruh Orientasi pasar Terhadap Kinerja pemasaran Pada PT.Umega Sembilan Berlian}

Berdasarkan hasil pengujian hipotesis pertama, ditemukan bahwa variabel orientasi pasar berpengaruh positif dan signifikan terhadap kinerja pemasaran pada PT.Umega Sembilan Berlian. Berdasarkan hasil uji t pada variabel orientasi pasar nilai signifikansiyang diperoleh sebesar 0,000 yang lebih kecil dari 0,05. Hal ini dapat diartikan bahwa variabel orientasi pasar berpengaruh positif dan signifikan terhadap kinerja pemasaran, dengan demikian, hipotesis pertama $(\mathrm{H} 1)$ dalam penelitian ini yang menyatakan bahwa orientasi pasar berpengaruh signifikan terhadap kinerja pemasaran pada pada PT.Umega Sembilan Berlian, dinyatakan diterima.

Hal ini bermakna tingkat kinerja pemasaran akan memberikan pengaruh yang signifikan terhadap kinerja pemasaran PT.Umega Sembilan Berlian, hal ini selaras dengan penelitian yang dilakukan oleh Imam Suroso (2010) dengan judul Pengaruh Karakteristik Pasar Dan Serta Kreativitas Terhadap Inovasi Dan Kinerja Pemasaran Perusahaan Kosmetik Di Provinsi Jawa Timur, menemukan bahwa orientasi pasar berpengaruh signifikan terhadap kinerja pemasaran, dan penelitian wahyono (2001) dengan judul Orientasi Pasar Dan Inovasi: Pengaruhnya 
Terhadap Kinerja Pemasaran, menemukan bahwa orientasi pasar berpengaruh signifikan terhadap kinerja pemasaran

\section{Pengaruh Kreatifitas Terhadap Kinerja pemasaran Pada PT. Umega Sembilan Berlian}

Berdasarkan hasil pengujian hipotesis kedua, ditemukan bahwa variabel kreatifitas berpengaruh positif dan signifikan terhadap kinerja pemasaran pada PT.Umega Sembilan Berlian. Berdasarkan hasil uji t variabel kreatifitas memiliki nilai signifikan sebesar 0,000 yang lebih kecil dari 0,05. Hal ini dapat diartikan bahwa variabel kreatifitas berpengaruh positif dan signifikan terhadap kinerja pemasaran, dengan demikian, hipotesis kedua $(\mathrm{H} 2)$ dalam penelitian ini yang menyatakan bahwa kreatifitas berpengaruh positif dan signifikan terhadap kinerja pemasaran pada PT.Umega Sembilan Berlian., dinyatakan diterima.

Hal ini bermakna kreatifitas akan memberikan pengaruh yang signifikan terhadap kinerja pemasaran PT.Umega Sembilan Berlian, hal ini selaras dengan penelitian yang dilakukan oleh Imam Suroso (2010) dengan judul Pengaruh Karakteristik Pasar Dan Serta Kreativitas Terhadap Inovasi Dan Kinerja Pemasaran Perusahaan Kosmetik Di Provinsi Jawa Timur, menemukan bahwa kreatifitas berpengaruh signifikan terhadap kinerja pemasaran, dan peneltian wahyono (2001) dengan judul Orientasi Pasar Dan Inovasi : Pengaruhnya Terhadap Kinerja Pemasaran, menemukan bahwa kreatifitas berpengaruh signifikan terhadap kinerja pemasaran.

Berdasarkan hasil penelitian penulis bahwa penelitian terdahulu dan penelitian sekarang sesuai dengan praktek lapangan yang dilakukan penulis.

\section{SIMPULAN}

Berdasarkan hasil penelitian penulis lakukan hal ini sesuai dengan praktek lapangan. Hal ini dapat ditarik kesimpulan sebagai berikut:

1. PT.Umega Sembilan Berlian bergerak dibidang Air Minum Dalam Kemasan (AMDK).

2. Hipotesis 1 diterima, Orientasi pasar berpengaruh positif dan signifikan terhadap kinerja pemasaran pada PT.Umega Sembilan Berlian.

3. Hipotesis 2 diterima, Kreatifitas berpengaruh positif dan signifikan terhadap loyalitas pada PT.Umega Sembilan Berlian .

4. Orientasi pasar dan kreatifitas signifikan terhadap kinerja pemasaran pada PT.Umega Sembilan Berlian artinya Orientasi pasar dan kreatifitas secara bersama-sama memiliki pengaruh yang positif dan signifikan terhadap variable dependennya.

\section{UCAPAN TERIMAKASIH}

Dengan selesainya penulisan artikel ini, penulis mengucapkan terima kasih kepada pihak-pihak yang membantu selama proses penulisan.

1. Bapak Febryandhie Ananda, SE, M.Si, selaku Ketua di STIE "KBP” Padang.

2. Ibu Lidya Martha, SE, MM selaku Wakil Ketua di STIE "KBP" Padang.

3. Ibu Febsri Susanti, SEI, MM selaku Ketua Program Studi Manajemen di STIE "KBP” Padang.

4. Ibu Maria Magdalena, S.Pd, MM, selaku Penasehat Akademik Program Studi Manajemen di STIE “KBP” Padang. 
5. Ibu Riri Mayliza, SE, MM, selaku Pembimbing Proposal Skripsi di STIE “KBP” Padang

\section{DAFTAR PUSTAKA}

Andika, A., \& Susanti, F. (2018). Pengaruh Marketing Mix Terhadap Keputusan Pembelian Parfum di Azzwars Parfum Lubeg Padang. https://doi.org/10.31227/osf.io/upgc3

Ardi, Rudi Prasetyo, and Ninik Sukmasari. 2016. "Pengaruh Disiplin Kerja , Promosi Jabatan Dan Kompensasi Terhadap Kinerja Pegawai Pada Dinas Kebudayaan Pariwisata Pemuda Dan Olahraga Kabupaten Rembang Effect of Work Discipline , Promotion and Compensation towards Employee Performance at the Department." Jurnal Manajemen 7(2): 105-10.

Aziz, N. (2019). Analisis Pengaruh Kualitas Produk, Harga, Promosi Terhadap Keputusan Pembelian Air Minum Dalam Kemasan (AMDK) Merek Aicos Produksi Pt. Bumi Sarimas Indonesia. https://doi.org/10.17605/OSF.IO/8XKYB

F., \& Susanti, F. (2019). Pengaruh Faktor Psikografis Terhadap Keputusan Pembelian Sepatu Merek Mollinic Di PT. Ramayana Lestari Sentosa, Tbk Padang. https://doi.org/10.31227/osf.io/26ftz

F., \& Afriyeni, A. (2019). Aktivitas Pemasaran Produk Tabungan Pada PT. Bank Pembangunan Daerah (BPD) Sumatera Barat Cabang Utama Padang. https://doi.org/10.31219/osf.io/tf2bz

Ghozali, Imam. 2011. "Aplikasi Analisis Multivariate Dengan Program IBM SPSS 20.” In Book, Semarang: Badan Penerbit Universitas Diponegoro, $1-298$.

Imam suroso. 2010. "Ipi253936.Pdf." Pengaruh orientasi pasar dan karakteristik, pasar serta kreativitas terhadap inovasi dan kinerja pemasaran perusahhaan kosmetik di provinsi jawa timur.

Kamener, Dahliana. 2017. "Faktor - Faktor Yang Mempengaruhi Kualitas Strategi Bersaing Industri Ukm Bordiran / Sulaman Di Kota Padang.” Journal of Economic and Economic Education 5(1): 90-105.

Marlius, D. (2017). Keputusan Pembelian Berdasarkan Faktor Psikologis Dan Bauran Pemasaran Pada PT. Intercom Mobilindo Padang. Jurnal Pundi. Volume 1. No. 1. Hal. 57-66. https://doi.org/10.31575/jp.v1i1.9

Marlius, D. (2016). Pengaruh Bauran Pemasaran Jasa Terhadap Minat Nasabah Dalam Menabung Pada Bank Nagari Cabang Muaralabuh. https://doi.org/10.31227/osf.io/vdqgx 
Mayliza, R. (2019). Pengaruh Kesadaran Merek, Asosiasi Merek Dan Perception Of Quality Terhadap Keputusan Pembelian Hospital Bed Merek Paramout Di PT. Aga Medika Utama Padang (Studi Kasus Rumah Sakit Umum Kota Padang). https://doi.org/10.17605/OSF.IO/VYQ4E

Prabowo, Novi Sely, and Azis Fathoni. 2016. "Pengaruh Kepuasan Kerja Dan Stres Kerja Terhadap Engangement Employee Dengan Turnover Intention Sebagai Variabel Intervening Pada PT. Ara Shoes Semarang." Jurnal Manajemen 1-7.

Sari, Lila Fitria. 2013. "Pengaruh rientasi Pasar Dan Kreativitas Terhadap Kinerja Pemasaran Pedagang Pakaian Jadi Di Pasar Kliwon Kbupaten Kudus." 3(2): 1-6.

Sugiyono. 2015. Book Statistik Nonparametris Untuk Penelitian. Bandung: CV. Alvabeta.

Susanti, F. (2018). Faktor Faktor Yang Mempengaruhi Minat Beli Pada ECommerce Lazada.co.id (Studi Pada Mahasiswa Jurusan S1 Manajemen "STIE KBP" Padang). https://doi.org/10.31227/osf.io/um4yw

Utaminingsih, Adijati. 2015. "Pengaruh Orientasi Pasar, Inovasi, Dan Kreativitas Strategi Pemasaran Terhadap Kinerja Pemasaran Pada Ukm Kerajinan Rotan Di Desa Teluk Wetan, Welahan, Jepara." Media Ekonomi Dan Manajemen 30(2): 161-77.

wahyono. 2001. "Orientasi Pasar Dan Inovasi : Pengaruhnya Terhadap Kinerja Pemasaran (Studi Kasus Pada Industri Meubel Di Kabupaten Jepara).”

Widayati, R. (2019). Aktivitas Pemasaran Produk Simpanan PT. Bank Tabungan Negara (Persero)Tbk Kantor Cabang Padang. https://doi.org/10.17605/OSF.IO/3Z5YC

Widayati, R. (2019). Aktivitas Pemasaran Produk Tabungan Pada PT. Bpr Rangkiang Denai Payakumbuh Barat. https://doi.org/10.17605/OSF.IO/S3UZM 